\title{
Study of Therapeutic Potential of Cryopreserved Newborn Rat Neural Cells in Rat Model of Intracerebral Hemorrhage
}

\author{
Ключевые слова: интрацеребральное кровоизлияние, крысы, криоконсервированные нейральные клетки, трансплан- \\ тация. \\ Ключові слова: інтрацеребральний крововилив, щури, кріоконсервовані нейральні клітини, трансплантація. \\ Key words: intracerebral hemorrhage, rats, cryopreserved neural cells, transplantation.
}

Интрацеребральное кровоизлияние (ИК), которое является причиной $15 \%$ всех инсультов, сопровождается тяжелыми осложнениями и ростом показателя смертности. В связи с этим необходима разработка методов, направленных на снижение выраженности проявлений ИК [3]. Одним из таких подходов может быть использование криоконсервированных нейральных клеток. Однако для применения данного метода необходимо определить способ и частоту введения клеток, а также их количество [7].

Цель работы - изучение влияния трансплантации первичной суспензии криоконсервированных клеток, полученных из головного мозга новорожденных крыс, на восстановление двигательной активности животных после интрацеребрального кровоизлияния.

Эксперименты проводили в соответствии с Законом Украины «О защите животных от жестокого обращения» (№ 3447-IV от 21.02.2006 г.) при соблюдении требований комитета Института по биоэтике проблем криобиологии и криомедицины НАН Украины (г. Харьков), согласованных с положениями «Европейской конвенции о защите позвоночных животных, используемых для экспериментальных и других научных целей» (Страсбург, 1986).

Моделирование ИК проводили на 11-13-месячных самцах белых беспородных крыс массой 250-350 г.

Лабораторія кріопротекторів, Інститут проблем кріобіології і кріомедицини НАН України, м. Харків
Intracerebral hemorrhage (ICH), being the cause of $15 \%$ in all the strokes, is accompanied by severe complications and high mortality rate. In this context the need arises in developing the novel methods aimed to reduce the IH symptom severity [1]. One of these approaches may be the use of cryopreserved neural cells. However, in order to apply this method it is necessary to determine the way and frequency of cell administration, and the needed amount as well [6].

This research was aimed to study the effect of transplantation of primary suspension of cryopreserved cells, derived from newborn rat brain on recovery of motor activity in animals after intracerebral hemorrhage.

The experiments were performed in accordance with the Law of Ukraine 'On the Protection of Animals Against Cruelty' (№ 3447-IV of February 21, 2006), in compliance with the requirements of the Bioethics Committee of the Institute for Problems of Cryobiology and Cryomedicine of the NAS of Ukraine, agreed to the statements of European Convention for the Protection of Vertebrate Animals Used for Experimental and Other Scientific Purposes (Strasburg, 1986).

ICH was simulated in 11-13-month-old white male outbred rats weighing 250-350 g. After preliminary anesthesia, the animals were placed in a stereotaxic device, then a hole into the skull was drilled (coor-

Laboratory of Cryoprotecyants, Institute for Problems of Cryobiology and Cryomedicine of National Academy of Sciences of Ukraine, Kharkiv, Ukraine

*To whom correspondence should be addressed:

23, Pereyaslavska str., Kharkiv, Ukraine 61016;

tel.:+380 573737435 , fax: +380 573735952

e-mail: kyrylozo@gmail.com

Received January, 26, 2018

Accepted February, 19, 2018

\footnotetext{
*Автор, якому необхідно надсилати кореспонденцію: вул. Переяславська, 23, м. Харків, Україна 61016; електронна пошта: kyrylozo@gmail.com 
После предварительной анестезии в черепе животных, помещенных в аппарат для стереотаксиса, просверливали отверстие (координаты от брегмы: переднезадняя - 0,2 мм, медиолатеральная с левой стороны - 3,0 мм), в которое через иглу диаметром 0,47 мм медленно (в течение 5 мин) на глубину 6,0 мм вводили 0,2 ЕД коллагеназы IV («Sigma-Aldrich», США) в 1 мкл физиологического раствора. Через 5 мин после введения иглу извлекали и на рану накладывали швы [12].

Крысам опытной группы $(n=4)$ через 2-е суток после формирования ИК трансплантировали $1,5 \times 10^{6}$ криоконсервированной первичной суспензии нейральных клеток, полученных из мозга новорожденных крыс [2], в 30 мкл среды DMEM/F12, животным контрольной группы $(n=9)-\mathrm{DMEM} / \mathrm{F} 12$ без клеток.

Количество трансплантированных клеток определяли по результатам исследований других авторов $[4,6,8,10]$.

Показатель жизнеспособности криоконсервированных нейральных клеток после размораживания и отмывания ДМСО соответствовал $(30,1 \pm 3,2) \%$. Суспензия состояла из дифференцированных, стволовых и прогениторных клеток [2].

Функциональные нарушения у крыс после ИК оценивали по результатам теста прохождения по перекладине, лестничного теста и теста углового поворота.

Тест прохождения по перекладине [5] проводили для оценки координации движений и способности удерживать равновесие. Для этого использовали цилиндрическую гладкую перекладину длиной 70 и диаметром 4 см, соединенную с темным ящиком, в котором находилась пища. Определяли общее количество соскальзываний передней и задней лап, контралатеральных от зоны поражения, а также скорость прохождения по перекладине (cм/c).

Лестничный тест [11] проводили для оценки воспроизведения крысами тонких навыков, приобретенных при обучении, - способности доставать с разной глубины лестницы съедобные гранулы. Для этого животных помещали в стеклянный бокс, по центру которого находился столик с прикрепленными по бокам 7-ступенчатыми лестницами. На каждой ступеньке лестницы находилось 3 гранулы по 45 мг каждая («Bio-Serv», США). Крысу после голодания помещали в бокс и подсчитывали количество съеденных в течение 15 мин гранул.

Тест углового поворота [9] использовали для оценки асимметрии поражения головного мозга крыс. Для выполнения теста крысу помещали в конструкцию, из 30-градусного угла которой она могла выйти, поворачиваясь и опираясь передними лапами к правой или левой стенке. Подсчитывали количество dinates from bregma of $0.2 \mathrm{~mm}$ anteroposterior, $3.0 \mathrm{~mm}$ left mediolateral), whereto using $0.47 \mathrm{~mm}$ needle we injected slowly (within $5 \mathrm{~min}$ ) to a depth of $6.0 \mathrm{~mm} 0.2 \mathrm{U}$ of collagenase IV (Sigma-Aldrich, USA) in $1 \mu$ of physiological saline. Five minutes after injection, the needle was removed and the wound was sutured [12].

The rats of experimental group $(n=4)$ in 2 days after $\mathrm{ICH}$ formation were subjected to transplantation with $1.5 \times 10^{6}$ cells of cryopreserved newborn rat brain-derived primary neural cell suspen-sion [10], in $30 \mu \mathrm{l}$ of DMEM/ F12, the control group animals $(n=9)$ received DMEM / F12 without cells.

The cell number needed for transplantation was determined by the reported data of other authors [3, 5, 7, 9].

The viability of cryopreserved neural cells after thawing and DMSO removal was $(30.1 \pm 3.2) \%$. The suspension consisted of differentiated, stem and progenitor cells [10].

Functional disorders in rats after $\mathrm{ICH}$ were assessed by the beam walking, staircase and corner turn test results.

The beam walking test [4] was performed to assess the motor coordination and ability to maintain postural equilibrium. For this purpose we used a cylindrical, smooth beam of $70 \mathrm{~cm}$ length and $4 \mathrm{~cm}$ diameter, connected to a dark box with food. The total number of forelimb and hindlimb, slips contralateral from the injured area, and the velocity of passage rate along the beam $(\mathrm{cm} / \mathrm{s})$ were assessed.

The staircase test [11] was done to evaluate how the rats could reproduce the fine skills acquired during training, $i$. e. the ability to take edible pellets from different depths of the staircase. For this purpose, the animals were placed into a glass box, in the center of which there was a table with 7-stepped staircases, attached to each side. At each staircase step there were 3 pellets, $45 \mathrm{mg}$ each (Bio-Serv, USA). A rat was put into a box after starvation and a number of pellets, eaten during 15 min was counted.

The corner turn test [8] was used to assess the asymmetry of brain injury in rats. In order to perform this test, the rat was placed into the construct from the corner $\left(30^{\circ}\right)$ of which it could exit, by turning and leaning with forelimbs onto the right or left wall. A number of turns in contralateral direction at 10-15 attempts was calculated.

The statistical significance of the studied parameters was determined by the Mann-Whitney test at $p=0.05$ [2].

To day 1 after ICH formation, the motor functions were significantly aggravated in rats, $i$. e. there were a loss of equilibrium, disorder in motor coordination and fine motor skill reproduction. According to the staircase test results, the average number of pellets, eaten by animals of both groups was established to equal 0.4 and 1.2, respectively (Fig. 1). We did not manage to determine 
поворотов животного в контралатеральном направлении при 10-15 попытках.

Статистическую значимость исследуемых показателей определяли по критерию Манна-Уитни при $p=0,05[1]$.

В первые сутки после моделирования ИК у крыс значительно ухудшались двигательные функции: потеря равновесия, нарушение координации движений и воспроизведения тонких навыков. По результатам проведения лестничного теста установлено, что среднее количество гранул, съеденных животными обеих групп, составило 0,4 и 1,2 соответственно (рис. 1). Количество соскальзываний и скорость прохождения по перекладине определить не удалось изза полной утраты крысами равновесия.

В первые сутки после формирования ИК все крысы при проведении теста углового поворота поворачивались при помощи лапы со стороны очага поражения (рис. 2). Данный факт указывает на выраженную асимметрию нарушений функций головного мозга.

У крыс опытной группы через сутки после введения криоконсервированных нейральных клеток (3-и сутки после формирования ИК) при выполнении лестничного теста наблюдалось статистически значимое по сравнению с контролем улучшение воспроизведения тонких навыков в 2,8 раза с контралатеральной стороны (см. рис. 1), среднее коли-

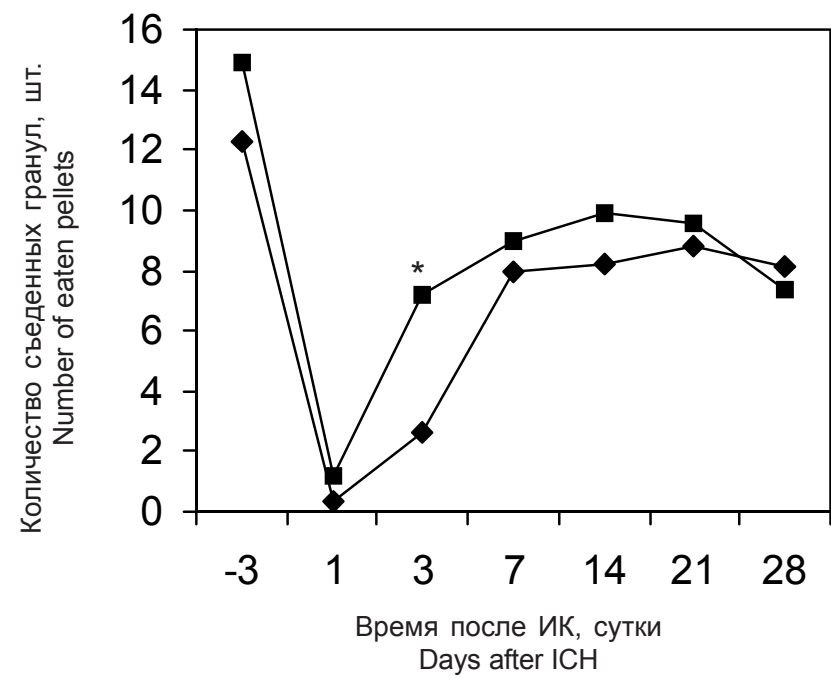

Рис. 1. Оценка влияния трансплантации криоконсервированных нейральных клеток на восстановление тонких навыков животных контрольной $(\bullet)$ и экспериментальной (ם) групп по результатам лестничного теста; * - отличия статистически значимы по сравнению с контролем, $p<0,05$.

Fig. 1. Assessment of cryopreserved neural cells transplantation effect on restoration of fine motor skills in animals of control $(\downarrow)$ and experimental $(\boldsymbol{\square})$ groups according to the staircase test results; ${ }^{*}$ - differences are statistically significant as compared with the control, $p<0.05$.

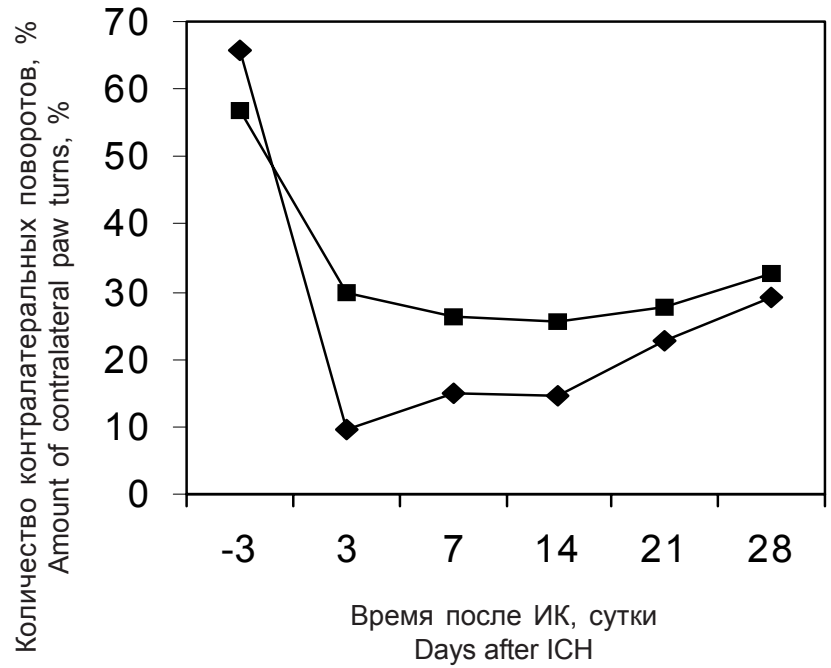

Рис. 2. Оценка влияния трансплантации криоконсервированных нейральных клеток на степень асимметрии поражения головного мозга животных контрольной $(\diamond)$ и экспериментальной $(\boldsymbol{\square})$ групп по результатам теста углового поворота.

Fig. 2. Evaluation of cryopreserved neural cells transplantation effect on brain injury asymmetry degree in animals of control $(\checkmark)$ and experimental ( $\boldsymbol{\square})$ groups by the corner turn test results.

a number of slips and passage rate along the beam in rats due to a complete loss of equilibrium.

To day 1 after ICH formation, when performing the corner turn test all the rats turned, aided by the limb on the lesion side (Fig. 2). This fact pointed to a pronounced asymmetry in brain dysfunction.

In rats of experimental group, 1 day after administering the cryopreserved neural cells (day 3 after ICH formation) when performing the staircase test was, observed a statistically significant 2.8 times improvement in fine motor skill reproduction from the contralateral side as compared with the control (see Fig. 1), the average number of slips in the beam walking test decreased in 3.3 times (Fig. 3A), the average passage rate along the beam increased in 3.1 times (Fig. 3B).

In rats of experimental group, performing the corner turn test was characterized with 3.2 times increase in the frequency of turns from the contralateral limb side but this change was statistically insignificant (see Fig. 2).

The indices of equilibrium and motor coordination in the beam walking test (see Fig. 3) tended to improve, $i$. e. to days 7 and 14 a number of slips decreased in 1.6 and 1.5 times, respectively. From day 21 to 28 the average passage rate along the beam in animals of experimental group decreased, herewith a number of slips from the beam was the same in both groups. In the corner turn test to days 7 and 14 the frequency of using contralateral limb increased in 1.8 times $v s$. the control. The tendency in increasing the frequency of contralateral limb use was also noted from day 21 to 28 . 

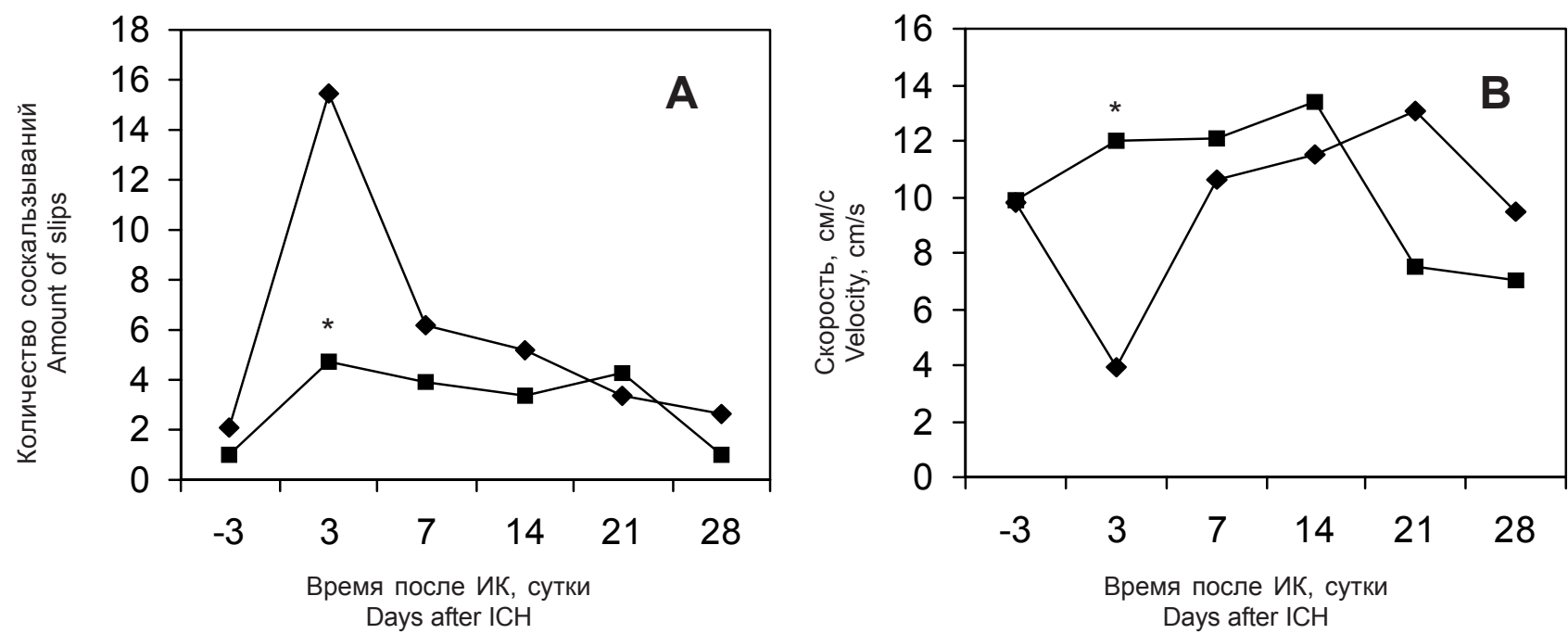

Рис. 3. Оценка влияния трансплантации криоконсервированных нейральных клеток на координацию движений (A) и скорость прохождения по перекладине $(\mathbf{B})$ животными контрольной $(\diamond)$ и экспериментальной (匚) групп по результатам теста прохождения по перекладине; * - отличия статистически значимы по сравнению с контролем, $p<0,05$.

Fig. 3. Assessment of cryopreserved neural cells transplantation effect on equilibrium function and motor coordination $(\mathbf{A})$ and beam walking rate (B) in animals of control $(\bullet)$ and experimental $(\boldsymbol{\square})$ groups by the beam walking test results; * differences are statistically significant in comparison with the control, $p<0.05$.

чество соскальзываний в тесте прохождения по перекладине уменьшилось в 3,3 раза (рис. 3, А), средняя скорость прохождения по перекладине увеличилась в 3,1 раза (рис. 3, В).

У крыс опытной группы при выполнении теста углового поворота частота поворотов по стороне контрлатеральной лапы увеличилась в 3,2 раза, однако этот показатель был статистически незначим (см. рис. 2).

Показатели равновесия и координации движений в тесте прохождения по перекладине (см. рис. 3) имели тенденцию к улучшению: на 7- и 14-е сутки количество соскальзываний уменьшилось в 1,6 и 1,5 раза соответственно. С 21-х по 28-е сутки средняя скорость прохождения по перекладине животных опытной группы снижалась, при этом количество соскальзываний с перекладины было одинаковым в обеих группах. В тесте углового поворота на 7- и 14-е сутки частота использования контралатеральной лапы увеличилась в 1,8 раза по сравнению с контролем. С 21-х по 28-е сутки также отмечалась тенденция к увеличению частоты использования контралатеральной лапы.

При проведении лестничного теста с 7-х по 28-е сутки наблюдалась тенденция к восстановлению тонких навыков у животных опытной группы.

Полученные результаты свидетельствуют о положительном эффекте трансплантации криоконсервированных нейральных клеток крысам с ИК, который проявлялся на 3-е сутки после введения и сохранялся (как тенденция к улучшению) на протяжении 14 суток.
The tendency to restore the fine motor skills in animals of experimental group was observed during staircase test performance from day 7 to 28 .

Our findings testify to a positive effect of cryopreserved neural cell transplantation to ICH rats, which was manifested to day 3 after administration and persisted (as a tendency to improve) for 14 days.

A decreased therapeutic effect of neural cells in 3 days after transplantation may be stipulated by their lysis due to both damaging effect of unfavorable factors, formed in the injured area and rejection reaction as well.

\section{References}

1. Andres R.H., Guzman R., Ducray A.D. et al. Cell replacement therapy for intracerebral hemorrhage. Neurosurg Focus 2008; 24(3-4): E15.

2. Atramentova L.O., Utevska O.M. Statistics for biologists: textbook. Kharkiv: NTMT; 2014.

3. Ben-Hur T., Idelson M., Khaner H. et al. Transplantation of human embryonic stem cell-derived neuronal progenitors improves behavioral deficit in Parkinsonian rats. Stem Cells 2004; 22(7): 1246-1255.

4. Beray-Berthat V., Delifer C., Besson V.C. et al. Long-term histological and behavioural characterisation of a collagenaseinduced model of intracerebral haemorrhage in rats. J Neurosci Methods 2010; 191(2): 180-190.

5. Cordeiro M.F., Horn A.P. Stem cell therapy in intracerebral hemorrhage rat model. World J Stem Cells 2015; 7(3): 618629. 
Ослабление терапевтического эффекта нейральных клеток через 3-е суток после трансплантации может быть обусловлено их лизисом вследствие как повреждающего действия неблагоприятных факторов, формируемых в зоне повреждения, так и реакции отторжения.

\section{Литература}

1. Атраментова Л.О., Утєвська О.М. Статистика для біологів: підручник. Харків: НТМТ; 2014. 331 с.

2. Ляшенко Т.Д., Сукач А.Н. Влияние различных концентраций ДМСО и замораживания-отогрева на сохранность нервных клеток новорожденных крыс. Проблемы криобиологии 2011; 21(3): 263-272.

3. Andres R.H., Guzman R., Ducray A.D. et al. Cell replacement therapy for intracerebral hemorrhage. Neurosurg Focus 2008; 24(3-4): E15.

4. Ben-Hur T., Idelson M., Khaner H. et al. Transplantation of human embryonic stem cell-derived neuronal progenitors improves behavioral deficit in Parkinsonian rats. Stem Cells 2004; 22(7): 1246-1255.

5. Beray-Berthat V., Delifer C., Besson V.C. et al. Long-term histological and behavioural characterisation of a collagenase-induced model of intracerebral haemorrhage in rats. J Neurosci Methods 2010; 191(2): 180-190.

6. Cordeiro M.F., Horn A.P. Stem cell therapy in intracerebral hemorrhage rat model. World J Stem Cells 2015; 7(3): 618-629.

7. Detante O., Jaillard A., Moisan A. et al. Biotherapies in stroke. Rev Neurol 2014; 170(12): 779-798.

8. Fukunaga A., Uchida K., Hara K. et al. Differentiation and angiogenesis of central nervous system stem cells implanted with mesenchyme into ischemic rat brain. Cell Transplantation 1999; 8(4): 435-441.

9. Hua Y., Schallert T., Keep R.F. et al. Behavioral tests after intracerebral hemorrhage in the rat. Stroke 2002; 33(10): 2478-2484.

10.Jeong S.W., Chu K., Jung K.H. et al. Human neural stem cell transplantation promotes functional recovery in rats with experimental intracerebral hemorrhage. Stroke 2003; 34(9): 2258-2263.

11.Montoya C.P., Campbell-Hope L.J., Pemberton K.D. et al. The "staircase test»: a measure of independent forelimb reach and grasping abilities in rats. J Neurosci Methods 1991; 36(2-3): 219-228.

12.Sang Y.H., Liang Y.X., Liu L.G. et al. A rat model of intracerebral hemorrhage permitting hematoma aspiration plus intralesional injection. Exp Anim 2013; 62(1): 63-69.
6. Detante O., Jaillard A., Moisan A. et al. Biotherapies in stroke. Rev Neurol 2014; 170(12): 779-798.

7. Fukunaga A., Uchida K., Hara K. et al. Differentiation and angiogenesis of central nervous system stem cells implanted with mesenchyme into ischemic rat brain. Cell Transplantat 1999; 8(4): 435-441.

8. Hua Y., Schallert T., Keep R.F. et al. Behavioral tests after intracerebral hemorrhage in the rat. Stroke 2002; 33(10): 24782484.

9. Jeong S.W., Chu K., Jung K.H. et al. Human neural stem cell transplantation promotes functional recovery in rats with experimental intracerebral hemorrhage. Stroke 2003; 34(9): 2258-2263.

10.Lyashenko T.D., Sukach A.N. The effect of DMSO of different concentrations and freeze-thawing on newborn rat neural cell survival. Probl Cryobiol Cryomed 2011; 21(3): 263-273.

11.Montoya C.P., Campbell-Hope L.J., Pemberton K.D. et al. The "staircase test": a measure of independent forelimb reach and grasping abilities in rats. J Neurosci Methods 1991; 36(2-3): 219-228.

12.Sang Y.H., Liang Y.X., Liu L.G. et al. A rat model of intracerebral hemorrhage permitting hematoma aspiration plus intralesional injection. Exp Anim 2013; 62(1): 63-69. 